DOI https://doi.org/10.36059/978-966-397-244-2-1-12

Колпаков В. К.

доктор юридичних наук, професор, завідувач кафедри адміністративного та господарського права Запорізький національний університет м. Запоріжжя, Украӥна

\title{
АДМІНІСТРАТИВНИЙ ПРОСТУПОК: З ПОЗИЦІЙ ДИНАМІЧНОГО ПРАВОРОЗУМІННЯ
}

В контексті існуючих уявлень про адміністративний проступок пропонується його дослідження з позицій динамічного праворозуміння. Динамічне порозуміння представлено у логіці дискусій щодо співвідношення позитивного і природнього у праві, як консолідуючий чинник посткласичної правової думки.

Методологічним засадами аналізу проступку обрані притаманні динамічному праворозумінню положення: а) право відтворюється в ході відносин між людьми; б) первинним $i$ безпосереднім адресатом норм позитивного права $\epsilon$ агенти влади, тобто суб'єкти їх застосування; в) правова норма це насамперед диспозиція законодавця, яка спрямована до носіїв владних повноважень щодо їх поведінки на випадок необхідності реагувати на вчинки звичайних людей; г) об'єктивацію динамічне праворозуміння знаходить, перш за все, в площині онтології.

Відповідно до цього, по-перше, розкрито онтологічну структуру феномена "адміністративний проступок», яка має фрактальну будову і структурується на складові генетично пов'язані: а) з природним правом; б) позитивним правом; в) правозастосовною практикою; по-друге, досліджено онтологічні ознаки проступку: а) діяння; б) його протиправність; в) винність; 2) караність.

\section{Вступ}

Протягом багатьох років проблематика проступку (правопорушення, делікту) займає виразне місце в адміністративноправових дослідженнях вітчизняних науковців. Це, наприклад, роботи Е. Додина «Субъект административного проступка» (1965); Л. Коваля «Відповідальність за адміністративні 
правопорушення» (1975); В. Колпакова «Профілактика адміністративних правопорушень та шляхи їі вдосконалення» (1983); В. Анджиєвського, І. Тимченко «Нове законодавство про адміністративні правопорушення» (1987); I. Голосніченка «Попередження корисливих проступків засобами адміністративного права» (1991); О. Остапенка «Адміністративна деліктологія: соціально-правовий феномен і проблеми розвитку» (1995); Т. Коломоєць «Штрафи за законодавством про адміністративні правопорушення» (1999); О. Недбайло «Законодавство про адміністративні проступки як складова частина адміністративного законодавства» (2000); Д. Лук'янця «Інститут адміністративної відповідальності: проблеми розвитку» (2001); T. Коломоєць «Система адміністративних стягнень за законодавством про адміністративні правопорушення» (2002); В. Колпакова «Адміністративно-деліктний правовий феномен» (2004); Т. Гуржія «Предмет адміністративного делікту» (2006); М. Самбора «Правопорушення та проступок: до питання співвідношення понять в умовах розвитку законодавства про адміністративні та кримінальні правопорушення» (2013); В. Колпакова, В. Гордєєва «Теорія адміністративного проступку» (2016); Ю. Битяка «Адміністративна відповідальність і адміністративне правопорушення (2020) та інших.

У кожному випадку дослідницькі зусилля генерували нові знання про адміністративно-деліктну дійсність відповідно до філософсько-теоретичного осягнення трансформацій феномену «праворозуміння» та їх інтерпретацій в галузевих сферах права.

Сучасна атрибуція «праворозуміння» $\epsilon$ результатом пошукових здобутків на шляху еволюції знань про його поняття: від дуалістичності (протистояння позитивного і природнього у праві) до динамічності (осмислення права мінливим, динамічним, процесуальним феноменом) і окресленням теоретичної конструкції «динамічного праворозуміння» [1, с. 78].

У спеціальних дослідженнях вона представлена консолідуючим чинником посткласичної правової думки, опосередкованої феноменолого-комунікативною (А. Поляков), діалогічною (I. Честнов), темпорально-онтологічною (А. Стовба), правової реальності (С. Максимов) концепціями і охарактеризована розумінням правових (юридичних) «модулів» не статичними, а динамічним, мінливими інгредієнтами в архітектоніці правових феноменів. 
Наведемо у якості приклада аналіз сприйняття юридичного факту «діяння» у класичному і динамічному (посткласичному) праворозумінні. У класиці це статичний фрагмент розташованого у просторі і часі випадку дійсності. Можна сказати, що це фотографія виокремленої за відповідними критеріями частки у в цілісному потоці подій. У динамічному праворозумінні «діяння» рухлива ситуація, органічний і системний сегмент фрактальної за своєю побудовою життєвої обставини.

Безпосередньо для нашого дослідження мають суттєве значення ще декілька суджень висловлених А. Стовбою стосовно природи динамічного праворозуміння. По-перше, він впроваджує урозуміння того, що право відтворюється в ході відносин між людьми; по-друге, обгрунтовує твердження, що первинним i безпосереднім адресатом норм позитивного права $\epsilon$ агенти влади, тобто суб'єкти їх застосування; по-третє, визнає норму диспозицією законодавця, яка спрямована до носіїв владних повноважень щодо їх поведінки на випадок необхідності реагувати на вчинки звичайних людей [2, с. 252].

3 наведених положень логічно випливає далекоглядний висновок про умовність прямого регулюючого впливу норм позитивного права на поведінку людей. Подальші галузеві дослідження у форматі цих суджень ведуть до перегляду змісту і поняття адміністративно-правових відносин, предмета адміністративного права, його доктрини та інститутів.

3 огляду на зазначене, неабиякий інтерес викликають дослідження адміністративного проступку 3 позицій динамічного праворозуміння.

\section{1. Феноменологія адміністративного проступку з позицій динамічного праворозуміння}

Адміністративний проступок, як явище об'єктивної реальності або феномен [3, с. 165], характеризується двоєдиним змістом [4]. По-перше, це життєва ситуація або подія, яка виникла у реальності і конфліктує з легітимними і інтуїтивно зрозумілими суспільству правилами поведінки.

По-друге, це абсолютно те ж саме явище (ситуація, подія), конфліктність якого «просканована» на предмет відповідності легальним компонентів зазначених правил. Тобто тим компонентам, які: а) відформатовані законом і набрали легальності; б) в силу цього стали обов'язковими для дотримання; 
в) захищені заходами відповідальності, які застосовуються до їх порушників. Фактично це норми адміністративно-деліктного законодавства, що встановлюють відповідальність за діяння (адміністративну відповідальність).

У першому випадку мова йде про онтологічний зміст проступку. Тут ознаки діяння видимі і доступні для сприйняття, оцінки, кваліфікації кожній людині відповідно до її уявлень про хороше і погане.

У другому випадку - про його гносеологічний зміст. Зміст, який утворюється в об'єктивній реальності як результат дослідження, (пізнання) характеристик проступку, результат підготовлений уповноваженими на то фахівцями. У цьому зв'язку зауважимо, що теза про «об'єктивну реальність» гносеологічних висновків базується на ідеях «нової» онтології Н. Гартмана. Він вважав, якщо вчені починають сумніватися в реальності того, що вони досліджують, їх наукові пошуки перестають бути пізнанням і перетворюються в фантазування [5].

Методом дослідження діяння виступають знання, що містяться в юридичних нормах, які кореспондуються з діянням. Результат такого пізнання - висновок (легальний висновок) про наявність чи відсутність в діянні реалізованих посягань на захищені заходами відповідальності порядки, правила, відносини. Наявність останніх наділяє діяння новими юридичними властивостями і характеристиками, які переводять його в статус правопорушення, а осіб, які його вчинили - в статус правопорушників.

Нормативне, легальне визначення адміністративного правопорушення (проступку) міститься в законодавстві. Перш за все, це стаття 9 Кодексу України про адміністративні правопорушення (далі КУпАП) [6], яка має назву «Поняття адміністративного правопорушення».

Вона встановлює, що адміністративним правопорушенням (проступком) визнається протиправна, винна (умисна або необережна) дія чи бездіяльність, яка посягає на громадський порядок, власність, права і свободи громадян, на встановлений порядок управління i за яку законом передбачено адміністративну відповідальність. Далі в ній уточнюється, що адміністративна відповідальність за проступки настає, якщо вони не тягнуть кримінальної відповідальності. 
Крім цього, законодавцем формулюються: 1) завдання КУпАП; 2) називаються критерії, за якими розмежовується а) вчинення адміністративного правопорушення умисно i б) вчинення адміністративного правопорушення 3 необережності; 3) описуються діяння, які визнаються адміністративними правопорушеннями.

Аналіз статей, в яких представлені ознаки проступку показує, що для їх опису використані два підходи. У першому випадку застосовано прямий перелік конкретних ознак діяння: протиправне, умисне, необережне і т.п. (ст. 9).

У другому випадку ознаки інтегровані в поняття «склад адміністративного проступку» - теоретичну (змістовну) абстракцію. Це зроблено не випадково. Йдеться про ознаки, які визначилися в результаті дослідження властивостей проступку, як мають практичне значення для висновків про ступінь i характер його кореляції з нормами закону. Ці ознаки і самі $€$ абстракцією - наслідком наукового осмислення емпіричних знань про адміністративний проступок.

Термін «склад адміністративного проступку» зафіксований в статті 247 КУпАП «Обставини, що виключають провадження у справі про адміністративне правопорушення». У ній зазначено, що провадження у справі про адміністративне правопорушення не може бути розпочато, а розпочате підлягає закриттю за відсутності в діянні складу адміністративного правопорушення.

3 цього випливає, що склад проступку - це системна сукупність його характеристик, ознак, властивостей за якими серед інших діянь виділяються адміністративні проступки як юридичні факти.

В даному контексті виникає питання: існує чи не існує принципова різниця між ознаками проступку: а) прямо зазначеними в законі і б) тими, які утворюють його склад. Відповідь на нього має бути такою: така різниця існує.

Ознаки, які безпосередньо перераховує закон, зокрема стаття 9 КУПАП, є ознаками апостеріорними (апостеріорі спирається на досвід, на факти, на знання про факти). Ознаки, які містить поняття «склад адміністративного проступку» $\epsilon$ ознаками апріорними (апріорі - заснований на умогляді, взятий зі свідомості).

Співвідношення апостеріорного і апріорного полягає в тому, що знання, які попередньо були отримані дослідним шляхом 
(апостеріорні знання, знання набуті з досвіду, емпіричні знання, істина факту), в подальшому передують досвіду, організують і направляють його. Виступають інструментом, який служить для отримання i формування нових знань теоретичного рівня (апріорні знання, знання набуті зі свідомості, теоретичні знання, істина розуму). Це відбувається шляхом формування та опису в законі передбачуваних (не зроблених) правопорушень. КУпАП містить такі опису в розділах 5 - 15-А.

Апостеріорні (емпіричні) ознаки адміністративного проступку фіксуються в законі як результат узагальнення історичного досвіду, детермінації небажаних для суспільства діянь. У бутті вони конкретизуються у видимі події з фізично відчутними наслідками, які вимірюються інтуїтивно зрозумілими кожній людині засобами (завдання шкоди, перешкоджання діям, порушення правил, складання протоколу, накладення штрафу). Їх нормативне закріплення $\epsilon$ орієнтиром для попередньої кваліфікації адміністративного правопорушення.

Наявність в діянні апостеріорного ознак ще не $\epsilon$ підставою для його визнання адміністративним проступком і настання юридичної відповідальності. Це підстава для подальшого дослідження (осмислення) всіх обставин вчинку у його динаміці, процесі, розвитку. В адміністративно-правовій теорії таке дослідження або осмислення позначається терміном «адміністративне розслідування».

Адміністративне розслідування проводиться з використанням апріорних (теоретичних) знань про ознаки адміністративного проступку. Такі знання містяться в навчанні про склад адміністративного проступку.

У разі, якщо результати розслідування доводять, що ознаки вчинку збігається з апріорними ознаками (ознаками складу), він набуває юридичного змісту як адміністративне правопорушення і виникають підстави для юридичної відповідальності.

Таким чином, апостеріорні ознаки забезпечують розпізнавання в розмаїтті життєвих ситуацій, вчинків та подій діянь, які мають підстави для їх визнання адміністративними правопорушеннями.

Апріорні ознаки забезпечують осмислення цих діянь з позицій права і доведення що вони $\epsilon$ в юридичному сенсі адміністративними правопорушеннями. Характеристика апріорних ознак збігається з характеристикою компонентів поняття «склад адміністративного проступку». 
Важливим питанням в розумінні суті адміністративного проступку $є$ його визнання діянням суспільно небезпечним або суспільно шкідливим. 3 цього приводу сформувалося дві основні концепції.

Перша концепція (суспільної небезпеки проступку) базується на генетичних зв'язках адміністративного проступку і злочину. Ї̈̈ представники виходять з природної єдності відповідних діянь і принциповою відмінністю між ними визнають тільки ступінь суспільної небезпеки.

Друга концепція (шкідливості адміністративних проступків) оформляється за радянських часів в якості альтернативи до першої. За нею адміністративні проступки не мають генетичних зв'язків зі злочинами або остаточно їх втратили. Тим самим вона зорієнтувалась на вирішення двох політико-правових завдань: поперше, демонструвався гуманізм кримінального законодавства (шляхом такого відмежування адміністративного проступку від злочину 3 кримінально-правового простору виводився величезний масив правопорушень); по-друге, відкривалася практично необмежена можливість збільшувати кількість складів правопорушень і суб'єктів юрисдикції. Таким чином, зазначена концепція служила для реалізації ідеологічних установок i політичного курсу того періоду. Ї̈ можна вважати своєрідним «візажистом» карального сегмента радянського права.

Суспільну небезпеку і суспільну шкодою, в контексті дослідження ознак адміністративного проступку, необхідно розглядати в діалектичній єдності і 3 урахуванням сучасних досягнень юридичних, філософських, соціологічних та інших наук. Такий підхід показує, що ці два поняття належать до різних рівнів узагальнення знань про адміністративний проступок.

Категорія «громадська шкідливість» $\epsilon$ онтологічною. Наявність шкоди, як правило, встановлюється шляхом опису реального факту зі сфери людської життєдіяльності. Його мета отримання детальної «фотографії» діяння зафіксованої в процесуальних документах (протоколах, поясненнях, актах і т.п). Такі документи $\epsilon$ онтологічними. Важливе місце в цій, онтологічної, «картині» належить опису заподіяної шкоди. Такий опис само по собі вже виступає доказом шкідливості відповідного діяння.

Категорія «суспільна небезпека» є гносеологічної. Це рівень оцінки діяння з позицій права і закону. Наявність або відсутність 
Новітні досягнення та вектори розвитку сучасної юриспруденції

суспільної небезпеки неможливо встановити шляхом онтологічного опису, тобто шляхом «фотографування» фактів. Вона повинна бути доведена.

Доведення здійснюється шляхом дослідження всіх сторін діяння. Його мета- виявлення властивостей, які на рівні теоретичних знань визначено юридичні ознаки проступку i відокремлюють його від інших шкідливих вчинків. Кінцевий результат доведення - встановлення наявності (або відсутності) складу адміністративного проступку (правопорушення).

Дослідження здійснюється у відповідних організаційних формах - справах про адміністративні правопорушення. Дії в рамках таких справ визначаються терміном розслідування. Такі справи за своєю суттю $\epsilon$ гносеологічним відображенням конкретного діяння. Розслідування справи - це пізнання (дослідження) факту реальної дійсності, в онтології якого виявилися ознаки правопорушення. Завершена справа $\epsilon$ гносеологічним відображенням конкретного діяння.

У справах про адміністративні правопорушення сконцентровані і систематизовані на матеріальних (предметних) носіях всі факти (обставини, докази), пов'язані з протиправним діянням. Такими носіями $\epsilon$ протоколи, акти, пояснення, розписки, фотографії та інші документальні свідчення, що відображають характеристики діяння. Вони містять знання як онтологічної (акт, протокол), так і гносеологічної (постанова) природи.

Таким чином, громадська шкідливість адміністративного правопорушення (проступку), передбачена статтями 10, 11 і 269 КУпАП, $є$ його апостеріорного ознакою. Ї̈̈ наявність, поряд 3 іншими апостеріорними ознаками, створює підстави для проведення адміністративного розслідування.

Суспільна небезпека $є$ апріорним ознакою адміністративного правопорушення (проступку). Вона характеризує головний компонент об'єктивної сторони складу адміністративного правопорушення - діяння.

На відміну від шкоди (шкідливості проступку), яка встановлюється за об'єктивними ознаками, висновок про суспільну небезпеку діяння $\epsilon$ результатом дослідження (пізнання) всіх суб'єктивних і об'єктивних факторів, які утворюють теоретичну категорію складу адміністративного правопорушення. 


\section{2. Онтологія адміністративного проступку}

\section{з позицій динамічного праворозуміння}

Своє відображення, свою об'єктивацію динамічне праворозуміння знаходить, перш за все, в площині онтології [7, с.67] і присутнє у всіх онтологічних проявах феномену (у нашому випадку феномену «адміністративний проступок»). Системна сукупність цих проявів утворює «онтологічний феномен проступку» (на відміну від «гносеологічного феномену проступку»).

Онтологічна структура феномену «адміністративний проступок» має фрактальну будову, у який детермінуються секторальні складові генетично пов'язані: а) 3 природним правом; б) позитивним правом; в) правозастосовною практикою

Численні дослідження адміністративного проступку (правопорушення, делікту) і сполученого з ним юридичної простору, сформували величезний масив наукових матеріалів, які, 3 одного боку, стимулюють аналітичну активність зростаючої кількості зацікавлених фахівців, а 3 іншого ускладнюють консолідацію мотивованих позицій, теоретичних напрацювань і юридичної практики, а в підсумку вироблення консенсусних рішень. Пропоноване дослідження орієнтоване на отримання нових знань про онтологію адміністративного проступку, тобто про його фактичні ознаки. Такими ознаками ми вважаємо діяння, а також його протиправність, винність, караність, об'єкт посягання.

Діяння. Первинним онтологічним сегментом у феменологічній картині адміністративного проступку $\epsilon$ конфліктні життєві ситуації, локалізовані у вчинках з ознаками протиправності і здатністю згенерувати своєрідні юридичні універсалії - поняття, принципи, застереження тощо[8, с. 57].

Однією 3 них є «діяння», яке в адміністративно-деліктному праві вважається найважливішою i визначальною ознакою адміністративного проступку. За статтею 9 КУпАП адміністративним правопорушенням (проступком) визнається саме діяння (дія чи бездіяльність), яке повинно характеризуватись низкою властивостей бути протиправним, винним, карним, зазіхати на відповідні цінності і завдавати їм шкоду.

I хоча зазначена стаття має назву «Поняття адміністративного правопорушення», вона такого поняття, як теоретично обгрунтованої концепції не дає, а лише вказує на ознаки, за 
якими подія що трапилась у матеріальному світі може бути розцінена як адміністративний проступок. Назвати її проступком, за вчинення якого особа повинна нести юридичну відповідальність, можна лише у разі встановлення шляхом доказування ознак об'єктивного і суб'єктивного характеру $[9$, c. 236].

Низка об'єктивних (або фактичних) ознак тих, що перелічені у статті 9 КУпАП, утворюють онтологічний компонент адміністративного делікту. Їх встановлення і відповідна фіксація формують базові і відправні підстави для дослідницьких (гносеологічних) висновків і прийняття рішення про визнання діяння адміністративним проступком.

Діяння (дія або бездіяльність), яке ще офіційно не визнано проступком, а являє собою лише один з видів юридичних фактів, $\epsilon$ відповідним вчинком (проступком) відповідного суб'єкта. Термін «діяння» $є$ узагальнюючою категорією, яка застосовується для позначення дії і бездіяльності разом (наприклад, коли особа вчиняє протиправні дію $\mathrm{i}$ бездіяльність одномоментно). У юридичній теорії і практиці він широко використовується також для позначення окремо дії і окремо бездіяльності, тобто як ïх синонім. На нашу думку таке використання терміну «діяння» $\epsilon$ коректним і відповідає розумінню синонімів як мовних одиниць 3 тотожною або максимально наближеною предметно-поняттєвою віднесеністю.

Протиправність. Однією 3 характеристик діяння як адміністративного проступку є протиправність. Саме ії̈ першою серед інших ознак називає законодавець у нормативному визначені адміністративного проступку, яке надає стаття 9 КУПАП.

У п'ятому томі Великій український юридичній енциклопедії $[10$, с. 43$]$ протиправність розглядається як юридичне вираження суспільної шкідливості поступку, яка $\epsilon$ його апостеріорною ознакою [11, с. 171]. Зазначимо з цього приводу, що в українській теорії права правопорушенням визнається протиправний акт поведінки, тобто такий, що порушує саме правову норму, а не будь-яку іншу із соціальних норм [12, с. 170].

Так, стаття 256 КУпАП «Зміст протоколу про адміністративне правопорушення» вимагає зазначати у цьому документі нормативний акт, який передбачає відповідальність за дії, що підпадають під ознаки проступку. 
Вона $\epsilon$ обов'язковим компонентом змісту постанови по справі про адміністративний проступок (стаття 283 КУПАП), тобто документу, який містить остаточні результати дослідження усіх обставин адміністративної справи і висновки щодо визнання відповідного діяння адміністративним проступком.

Отже, законодавець, таким чином, підкреслює нерозривний зв'язок протиправності адміністративних проступків як з їхньою шкідливістю, так і з їхньою суспільною небезпечністю. При цьому, якщо суспільна небезпечність і шкідливість характеризують змістовну сторону адміністративного проступку, то протиправність його юридичну форму (оболонку).

Ознака протиправності використовується законодавцем для розмежування злочинів і адміністративних деліктів, адміністративних деліктів між собою, адміністративних деліктів i дисциплінарних проступків. Це дозволяє правозастосовним органам юридично точно кваліфікувати різні протиправні діяння, а особливо такі, що мають подібні ознаки.

Невірне визначення в законі границь протиправності може привести до того, що, по-перше, правопорушеннями будуть штучно визнані діяння, що не $\epsilon$ шкідливими; по-друге, безкарними залишаться небажані в нашому суспільстві явища. Тому будь-які маніпуляції з законодавством (штучне введення норм чи їхнє скасування) можуть здійснюватися лише у вузьких межах і в остаточному підсумку визначатися змістом об'єктивних потреб розвитку суспільства.

Отже, адміністративна протиправність (незважаючи на відносну рухливість їі границь), в остаточному підсумку, є лише юридичною формою вираження шкідливості діяння та їі гносеологічного супутника суспільної небезпеки. Звідси випливає таке: діяння, навіть будучи об'єктивно шкідливим, не може розглядатися як адміністративне правопорушення якщо не буде визнано протиправним.

Дане положення відбиває об'єктивний взаємозв'язок i взаємозумовленість адміністративної протиправності, шкідливості і суспільної небезпеки делікту. Це виявляється в тім, що: а) шкідливі властивості діяння, які не зафіксовані в адміністративно-деліктній нормі, позбавлені юридичної чинності; б) якщо норма адміністративно-деліктного закону, у силу різних об'єктивних обставин перестає відповідати існуючим суспільним 
Новітні досягнення та вектори розвитку сучасної юриспруденції

відносинам, то вона перестає об'єктивно виконувати свою роль регулятора цих відносин.

Винність. Протиправність адміністративного проступку знаходиться в нерозривному зв'язку з винністю особи у його вчиненні. I якщо адміністративна протиправність характеризує діяння з боку його юридичної форми, тобто зовнішнього прояву, то винність характеризує його внутрішню, суб'єктивну сторону, розкриває відношення до проступку особи, що цей проступок вчинила, тобто правопорушника.

У ст. 9 КУПАП, по-перше, визначає винність обов'язковою ознакою проступку, по-друге, вказує на її форми умисна або необережна. Поняття форм вини деталізовано у статтях 10 і 11 Кодексу.

За статтею 10 КУпАП адміністративний проступок визнається вчиненим умисно, коли особа, яка його вчинила, усвідомлювала протиправний характер своєї дії чи бездіяльності, передбачала іiї шкідливі наслідки і бажала або свідомо допускала настання цих наслідків.

За статтею 11 КУпАП адміністративний проступок визнається вчиненим коли особа, яка його вчинила, передбачала можливість настання шкідливих наслідків своєї дії чи бездіяльності, але легковажно розраховувала на їх відвернення або не передбачала можливості настання таких наслідків, хоч повинна була і могла їх передбачити.

За до статтею 251 «Докази», наявність вини встановлює компетентний орган (посадова особа). Данні про винність встановлюються протоколом про адміністративне правопорушення, поясненнями особи, яка притягається до адміністративної відповідальності, потерпілих, свідків, висновком експерта тощо. Частина друга цієї статті містить норму, яка покладає на осіб, уповноважених на складання протоколів про адміністративні правопорушення, обов'язок збирання доказів. Таким чином, доведення винності відповідної особи $є$ прямим обов'язком суб'єкта, який склав протокол про адміністративні правопорушення, а сам протокол має містити фіксацію винності.

У той же час, стаття 14-1 «Відповідальність власників (співвласників) транспортних засобів» передбачає складання протоколу и винесення постанови про накладення штрафу на особу, вина якої не встановлена. Ситуація виникає при фіксації проступку спеціальними технічними засобами, працюючими в 
автоматичному режимі, коли транспортним засобом керувала третя особа, а документ про притягнення до відповідальності оформлений на його власника ідентифікованого по державному номерному знаку транспортного засобу.

Розуміючи реальність виникнення таких ситуацій, законодавець встановив норму, за якою власник (співвласник) транспортного засобу може протягом десяти днів з дня вручення йому постанови про накладення штрафу повідомити про відповідні обставини суб'єкта, що виніс постанову про накладення адміністративного стягнення. На період з'ясування та перевірки цих обставин виконання постанови про накладення адміністративного стягнення зупиняється до моменту встановлення особи, яка вчинила це правопорушення.

Таким чином, збирання доказів вини перекладається на особу, яка притягується до відповідальності, що протирічить частині другій ст. 251 КУпАП.

Врегулювання цієї колізії, на наш погляд, може бути здійснено шляхом нормативного тлумачення терміну «повідомити про відповідні обставини», можливо шляхом доповнення статті 14-1 новою частиною.

Караність. Термін «караність» у описах властивостей адміністративного проступку (або відповідальності за його вчинення) в адміністративно-деліктному законодавстві не зустрічається. Сфера його застосування наукові дискусії, публіцистика і навчальні матеріали.

Він означає, що наслідком проступку обов'язково $€$ застосування примусових заходів, які встановлені нормами закону. У нормах КУпАП відповідне змістовне навантаження корелюється 3 терміном «стягнення».

3 нормативних i наукових інтерпретацій випливає, що «стягнення» це примусовий захід впливу і міра відповідальності, яка застосовується 3 метою виховання правопорушника i запобігання вчиненню нових правопорушень як самим правопорушником, так і іншими особами.

Генетичні зв'язки адміністративних проступків i злочинів спонукають до порівняння каральних екстракцій адміністративноделіктного кримінально-правового просторів.

Для кримінального права терміни i поняття «кара», «караність», «покарання» є органічними феноменами і присутні у нормах Кримінального кодексу України. Зокрема, він визнає 
покарання заходом примусу, який застосовується від імені держави за вироком суду і має на меті у тому разі і кару (ст. 50 КК). Таким чином, законодавство про кримінальну відповідальність фактично визнає кару метою покарання.

Законодавство про адміністративну відповідальність (ст. 23 КУпАП) напряму стягнення з покаранням і карою не зв'язує. Воно $\epsilon$ мірою відповідальності і застосовується у виховних і профілактичних цілях.

Така ситуація дала можливість на відповідному етапі розвитку адміністративно-деліктних знань припустити, що таким чином законодавець підкреслив якісну відмінність санкцій, які застосовуються за вчинення адміністративного проступку від санкцій, які застосовуються за вчинення злочину $[13$, с. 36$]$.

Дослідження цього співвідношення [14, с.108] доводять доречність визнання караності однією 3 необхідних ознак адміністративного проступку.

Об'єкт посягання. Онтологічна структура об'єкту посягання адміністративного делікту представлена у статті 9 КУпАП. Це громадський порядок, власність, права і свободи громадян, встановлений порядок управління.

Термін «громадський порядок» у чинному законодавстві України використовується з помітним ступенем інтенсивності. Достатньо нагадати, що у Конституції України він зустрічається у 6 статтях, у КУпАП у 16 статтях, у Кримінальному кодексі України у 9 статтях. Втім його нормативне визначення як юридичного поняття законодавець не дає.

у доробках українських адміністративістів [15] він розглядається як система суспільних відносин, що складаються в результаті додержання юридичних і моральних норм, а також правил-звичаїв.

Належній громадський порядок створює сприятливі умови для успішного розвитку суспільства в цілому, ефективного функціонування його соціальних інститутів. Винятково велика його роль у забезпеченні чіткої і злагодженої роботи державного апарата, діяльності громадських організацій.

У диспозиціях статей КУпАП він зустрічається лише один раз. Це стаття 173 «Дрібне хуліганство», яка передбачає відповідальність за дії, що порушують громадський порядок.

у деяких джерелах i практиці роботи правоохоронних суб'єктів у якості його синоніма почали використовувати термін 
«публічний порядок». На нашу думку це недостатньо обгрунтована альтернатива, від якої доречно відмовитись [16].

Наступним об'єктом посягання стаття 9 КУпАП визначає власність. Відповідно до Конституції України держава забезпечує захист прав усіх суб'єктів права власності, які $\epsilon$ рівними перед законом, а використання власності не повинно завдавати шкоди правам, свободам та гідності громадян, інтересам суспільства.

КУПАП містить окрему главу щодо проступків проти власності. Це глава 6 «Адміністративні правопорушення, що посягають на власність». Необхідно зазначити, що законодавець залишив за межами цієї спеціальної глави значну кількість діянь, що фактично посягають на власність, віддавши перевагу іншим класифікаційним критеріям.

Такими діяннями $є$ самовільне зайняття земельної ділянки (стаття 53-1), самовільна забудова площ залягання корисних копалин (стаття 57), незаконне використання земель державного лісового фонду для спорудження будівель (стаття 63), знищення дренажних систем і шляхів на землях державного лісового фонду (стаття 74) та інші.

Серед дій, які можуть кваліфікуватися за чинним адміністративно-деліктним законодавством як посягання на власність, КУпАП називає: самовільне користування власністю (статті 47 і 48); самовільне використовування власності (стаття 51-2); самовільне захоплення власності (стаття 48); укладення угод, які в прямій чи прихованій формі порушують право власності (статті 47, 48, 49, 50); самовільну переуступку права користування власністю (статті 48, 49, 50); дрібне розкрадання державного або колективного майна (стаття 51); привласнення авторства (стаття 51-2).

Таким чином, адміністративно-деліктними санкціями захищені усі передбачені законодавством форми власності (приватна, колективна, державна) і зовнішні прояви права на власність (володіння власністю, користування власністю, розпорядження власністю).

Серед об'єктів захисту від адміністративно-деліктних посягань особливе місце належить правам $\boldsymbol{i}$ свободам громадян. Воно обумовлено конституційним характером зазначених категорій. Саме Конституція України у розділі II «Права, свободи та обов'язки людини і громадянина» закріплює 
комплекс прав, свобод і обов'язків людини і громадянина як певну систему, складовими якої виступають особисті, громадянські, політичні, соціальні, економічні, культурні та екологічні права і свободи. Вони забезпечують кожній особі можливість бути самостійним суб'єктом суспільного життя і визначають правовий статус людини і громадянина.

В адміністративно-деліктному сегменті питання захисту прав і свобод громадян регламентовано нормами як Особливої так і Загальної частин КУпАП. Так, наприклад, найменування відповідних глав Особливої частини кодексу вказують на види прав громадян, що знаходяться під захистом включених до них норм. Наприклад, глава 5 «Адміністративні правопорушення в галузі охорони праці і здоров'я населення»; глава 11 «Адміністративні правопорушення в галузі житлових прав громадян, житлово-комунального господарства та благоустрою»; глава 12 «Адміністративні правопорушення в галузі торгівлі, громадського харчування, сфері послуг, в галузі фінансів і підприємницькій діяльності».

Останнім об'єктом посягання, з тих, що визначені у статті 9 КУПАП, є встановлений порядок управління. У контексті цієї статті, під порядком управління необхідно розуміти систему юридичних правил, що утворюють механізм владного, цілеспрямованого, організуючого впливу на суспільні відносини з боку владних інституцій з метою їх вдосконалення відповідно до публічних інтересів.

Посягання на порядок управління законодавець визначає як порушення порядку, правил, строків, приписів (184-2, 185-1, 185-3, 186, 186-2 187, 189 192, 194 211, 211-2 211-6, 212-2 статті КУпАП); невиконання законних вимог уповноважених осіб або непокора їм $(185,185-3,185-9,185-10,188-1,188-3$ 188-15 статті КУПАП); неправомірне, недбале, незаконне використання (184-1, 198, 211 статті КУпАП); ухилення від обов'язків (185-3, 185-4, 185-6, 185-8, 188-2, 193, 211-2, 211-4, 212-1 статті КУпАП); здійснення дій, що сприяють або викликають правопорушення, або інші шкідливі, суспільно небезпечні діяння (185-2, 185-7, 185-11, 188 статті КУПАП); незаконні дії $(185-5,186,186-1,211-1,211-3$ статті КУПАП). 


\section{3. Формалізація феноменологічних ознак}

\section{адміністративного проступку}

Домінуючим процесуальним документом в сфері адміністративно-деліктних відносин, який формалізує феменологічні (онтологічні i гносеологічні) характеристики адміністративного проступку $є$ протокола про адміністративне правопорушення.

Головні параметри його статусу визначає Кодекс України про адміністративні правопорушення. Втім, важливі положення 3 цього приводу містять і інші документи.

Так, Митний кодекс України [17] при регламентації процесуальних дій включає до їх переліку складення протоколу про порушення митних правил (ст. 508). Одномоментно у ст. 458 кваліфікує порушення митних правил як адміністративне правопорушення. Таким чином, законодавець визнає протокол про адміністративне правопорушення процесуальним документом, який складається в межах адміністративноделіктного процесу. Більш того, цей процес (провадження у справі про порушення митних правил) вважається розпочатим 3 моменту складення протоколу про порушення митних правил (ст. 489). Зауважимо також, що Митний кодекс України підкреслює домінуюче значення КУпАП в адміністративноделіктній сфері. Зокрема, у його стаття 487 встановлює, що провадження у справах про порушення митних правил в частині, що не регулюється Митним кодексом України, здійснюється відповідно до законодавства України про адміністративні правопорушення.

Виходячи з вище зазначеного, протокол про адміністративне правопорушення це процесуальний документ, у якому фіксується юридичний факт з ознаками адміністративного проступку. Він $\epsilon$ однією 3 документальних підстав адміністративної відповідальності [18, с. 759].

КУпАП детально регламентує підстави та порядок складання протоколу (у тому числі випадки, коли протокол не складається); визначає осіб, які мають право його складати; зміст протоколу; осіб та органи, яким він надсилається; закріплює його зв'язок з такими процесуальними діями як доставлення порушника; забезпечення провадження у справах про адміністративні правопорушення; встановлення доказів щодо наявності чи відсутність проступку і винності особи в його вчиненні; 
визначення строків розгляду справ; підготовка до розгляду справи; порядок розгляду справи та іншими обставинами, що впливають на ї̈ вирішення відповідно до закону.

Стаття 256 КУпАП встановлює обов'язковий перелік відомостей та атрибутів, які мають у ньому міститися у протоколі. Вони поділяються на три групи. По-перше, це відомості, що стосуються обставин вчинення адміністративного правопорушення. У протоколі зазначаються місце, дата і суть вчиненого діяння. В обов'язковому порядку точно вказується стаття КУпАП, що передбачає адміністративну відповідальність за відповідне правопорушення. У разі вилучення у порушника предметів або документів до протоколу заноситься відповідний запис.

По-друге, це відомості про особу, на дії якої складено протокол: прізвище, ім'я, по батькові, вік, рід занять, матеріальне становище, місце проживання і роботи, документ, що посвідчує особу (паспорт або інший документ).

По-третє, це відомості, що стосуються форми протоколу. Тут вказуються дата і місце його складання, прізвище і посада працівника, який оформив протокол (відсутність відомостей про нього робить його дефектним, оскільки невідомо, чи складений він повноважною на те особою чи ні); прізвище і адреса свідків і потерпілих, якщо вони $\epsilon$.

Протокол скріплюється кількома підписами. Насамперед він мас бути підписаний особою, яка його склала, та правопорушником. За наявності свідків і потерпілого протокол підписують також ці особи.

Особі, яка притягується до відповідальності, необхідно роз'яснити її права та обов'язки, передбачені ст. 268 КУпАП, про що робиться відмітка у протоколі. Вона має право ознайомитися зі змістом протоколу, занести власні пояснення, підписати його або відмовитися від підпису та вказати мотиви відмови, надати пояснення або зауваження щодо змісту протоколу, які до нього додаються. Відмова правопорушника підписати протокол не зупиняє подальшого руху справи, але цей факт має бути зафіксований спеціальним записом.

У разі вчинення проступку групою осіб протокол складається на кожного порушника окремо. Складання одного протоколу на всіх правопорушників не дає змоги конкретизувати звинувачення, що ставиться кожному 3 них, позбавляє 
можливості прямо у протоколі дати свої пояснення щодо сутності проступку, обмежує право особи на захист у разі притягнення ії до адміністративної відповідальності.

Належним чином оформлений протокол надсилається органу (посадовій особі), уповноваженому розглядати справу про адміністративне правопорушення. Протокол про вчинення корупційного діяння разом з іншими матеріалами у триденний строк 3 моменту складення надсилається до місцевого загального суду за місцем його вчинення. У разі вчинення корупційного діяння службовою особою, яка працює в апараті суду, протокол разом з іншими матеріалами надсилаються до суду вищої інстанції для визначення підсудності.

Особа, яка склала протокол про вчинення адміністративного корупційного правопорушення, одночасно з надісланням його до суду надсилає органу державної влади, органу місцевого самоврядування, керівникові підприємства, установи чи організації, де працює особа, яка притягається до відповідальності, повідомлення про складення протоколу із зазначенням характеру вчиненого правопорушення та норми закону, яку порушено.

Право складати протоколи про адміністративні правопорушення надано особам, перелік яких містить стаття 255 КУпАП. Важлива особливість ії конструкції полягає у тому, що уповноважені особи не просто перелічуються, а «прив'язуються» до кожної окремої статті або частини статті Особливої частини КУпАП. Таким чином, стаття 255 КУпАП врегулювала підвідомчість питань щодо кваліфікації діянь як адміністративних правопорушень в процесі їх фіксації.

Така «прив'язка» здійснена за двома критеріями. По-перше, за характером зв'язків уповноважених суб'єктів 3 органами (структурами) публічної адміністрації; по-друге, за наявністю компетенції щодо вирішення справ про адміністративні проступки. Відповідно до цього, у їх сукупності виокремлюється декілька груп.

До першої групи належать особи, які наділяються правом розглядати справи про адміністративні правопорушення i накладати адміністративні стягнення. Вони мають право складати протоколи за вчинення тих самих проступків, за які уповноважені накладати стягнення. 
Так, наприклад, знищення або пошкодження відмежувальних знаків у лісах $\epsilon$ адміністративним правопорушенням, відповідальність за вчинення якого передбачена статтею 75 КУпАП. Рішення про накладення стягнення за даною статтею приймають представники органів лісового господарства, які перелічені у ст. 241 КУпАП. Вони ж наділені і правом складати протоколи щодо таких вчинків.

До другої групи належать посадові особи, які уповноважені на складання протоколів відповідними органами виконавчої влади. Наприклад, центральним органом виконавчої влади, що реалізує державну політику у сфері енергозбереження (статті 98, 101-103, 188-14); центральним органом виконавчої влади, що реалізує державну політику у сфері ветеринарної медицини (статті 42-1 $42-3,107,188-22)$; центральним органом виконавчої влади, що реалізує державну політику у сфері лісового господарства (частини друга і п'ята статті 85, статті 85-1, 88-1, 90); центральним органом виконавчої влади 3 питань цивільної авіації (частина друга статті 112 , частина третя статті 133) тощо.

До третьої групи належать посадові особи, які повноваження на складання протоколів мають від інших (крім органів виконавчої влади) державних органів. Це, наприклад, органи Служби безпеки України, що визначена державним правоохоронним органом спеціального призначення, який забезпечує державну безпеку України (статті 172-4 172-9, 195-5, 212-2 та інші).

До четвертої групи належать посадові особи, які мають повноваження на складання протоколів від суб'єктів, які створені на виконання парламентських функцій. Так, посадові особи відділу контролю Апарату Верховної Ради України складають протоколи про адміністративні правопорушення, передбачені статтею 188-19 «Невиконання законних вимог народного депутата України, Рахункової палати, члена Рахункової палати».

До п'ятої групи належать посадові особи, які мають повноваження на складання протоколів від суб'єктів, які спеціально утворені для здійснення контролю i нагляду. Наприклад, органами державного нагляду у сфері пожежної і техногенної безпеки (статті 164, 183, 188-16); органами державного контролю за додержанням законодавства про захист прав споживачів (статті 42-2, 156, 164-6, 164-7); органами державного нагляду (контролю) у сфері охорони навколишнього природного середовища, раціонального використання, 
відтворення і охорони природних ресурсів (частини друга, четверта та п'ята статті 85, статті 85-1, 88, 88-1, 88-2, 90, 91).

До шостої групи належать посадові особи, які повноваження на складання протоколів мають від органів місцевого самоврядування, наприклад, виконавчих комітетів сільських, селищних, міських рад. Вони складають протоколи про порушення заборон, встановлених рішеннями відповідних рад (ст. 175-1 «Куріння тютюнових виробів у заборонених місцях» та інші).

До сьомої групи належать особи, які мають право складати протоколи про адміністративні правопорушення, що виявилися у ході здійснення юридичних процесуальних дій. Це слідчий (частина четверта статті 184, статті 185-4, 185-11), прокурор (статті 172-4 172-20, 185-4, 185-8, 185-11), судовий розпорядник (стаття 185-3), секретар судового засідання, секретар суду (стаття 185-5, частина перша статті 185-6), державні виконавці (стаття 188-13).

До восьмої групи входять особи, які є суб'єктами виборчого процесу або представниками суб'єкта виборчого процесу. Це голова, заступник голови, секретар, інші члени виборчої комісії, комісії з референдуму (статті 212-7, 212-9, 212-11 212-20), кандидати, уповноважені особи, офіційні спостерігачі (статті 212-16 212-18, 212-20).

До дев'ятої групи входять особи, які при оформлені протоколу виступають представниками відповідного підприємства, установи, організації. Це, наприклад, власник підприємства, установи, організації або уповноважений ним суб'єкт (ст. 51, 179); працівники, які здійснюють охорону підприємств, установ, організацій (стаття 179).

До десятої групи входять особи які виконують відповідні повноваження на громадських засадах або $\epsilon$ уповноваженими особами добровільних об'єднань громадян, інших колегіальних органів. Такими, наприклад, є: член громадського формування 3 охорони громадського порядку і державного кордону (статті 92, $148,152,154,160,175-1,179,185-7,186-2,186-4)$; громадські інспектори (Українського товариства охорони пам'яток історії та культури; 3 охорони довкілля); голова ради адвокатів або уповноважений радою член ради адвокатів (стаття 212-3 у частині, що стосується порушення права на інформацію відповідно до Закону України «Про адвокатуру та адвокатську 
Новітні досягнення та вектори розвитку сучасної юриспруденції

діяльність»); голова, заступник голови Вищої ради юстиції (стаття 188-32) тощо.

Наведений перелік не $\epsilon$ вичерпним. Відповідно до частини третьої статті 255 КУпАП у випадках, прямо передбачених законом, протоколи про адміністративні правопорушення можуть складати також посадові особи інших органів державної влади, органів місцевого самоврядування і представники органів самоорганізації населення.

Так, стаття 2 КУпАП встановлює, що його положення поширюються i на адміністративні правопорушення, відповідальність за вчинення яких передбачена законами, ще не включеними до Кодексу, а питання щодо адміністративної відповідальності за порушення митних правил регулюються Митним кодексом України (із змісту норм КУПАП і Митного кодексу України випливає, що порушення митних правил $\epsilon$ адміністративним правопорушенням, за вчинення якого передбачена адміністративна відповідальність).

У свою чергу, Митний кодекс визнає протокол про порушення митних правил процесуальним документом (ст. 495), а його складання регламентує як окрему процесуальну дію (ст. 508). Встановлює, що протокол складається про кожний випадок виявлення порушення митних правил (ст. 494) уповноваженими на те особами (ст. 490). Відповідно до статті 488 Митного кодексу провадження у справі про порушення митних правил вважається розпочатим 3 моменту складення протоколу про таке порушення.

Важливе значення для розуміння ролі і місця протоколу про адміністративне правопорушення в адміністративно-деліктному процесі має регламентація випадків, коли протокол про таке правопорушення не складається. Вони визначені у статті 258 КУПАП.

Основні критерії їх детермінації такі: 1) обмеження розміру штрафу за проступок 3 неоподатковуваними мінімумами доходів громадян (в разі вчинення адміністративних правопорушень, передбачених статтями 70, 77, частиною третьою); 2) обмеження розміру штрафу за проступок 7 неоподатковуваними мінімумами доходів громадян (в разі вчинення адміністративного правопорушення, передбаченого частиною першою статті 85); 3) погодження правопорушника з накладенням адміністративного стягнення (в разі вчинення адміністративних правопорушень, 
передбачених статтею 107 (у випадках вчинення правопорушень, перелічених в частині третій статті 238) частиною третьою статті 109 , статтями 110,115 , частинами першою, третьою і п'ятою статті 116, частиною третьою статті 116-2, частинами першою і третьою статті 117 (при накладенні адміністративного стягнення у вигляді попередження на місці вчинення правопорушення), статтями 118, 119, статтями 134, 135, 185-3 КУПАП); 4) автоматичний режим фіксації правопорушень у сфері забезпечення безпеки дорожнього руху за допомогою спеціальних технічних засобів, що мають функції фото- і кінозйомки, відеозапису чи засобів фото- і кінозйомки, відеозапису.

\section{Висновки}

Таким чином, дослідження феноменологічних властивостей адміністративного проступку 3 позицій динамічного праворозуміння, дає підстави для констатації наступного: а) останнім часом зростає інтерес до проблем детермінації адміністративних правопорушень у сфері протиправної поведінки і, тим самим, до коректного розуміння їх онтологічних (фактичних) ознак, досліджених з позицій динамічного праворозуміння; б) адміністративна протиправність (незважаючи на відносну рухливість її границь), в остаточному підсумку, є лише юридичною формою вираження шкідливості діяння та її гносеологічного супутника суспільної небезпеки, що дає підстави зазначити таке: діяння, навіть будучи об'єктивно шкідливим, не може розглядатися як адміністративне правопорушення якщо не буде визнано протиправним; в) низка об'єктивних (або фактичних) ознак (перелічені у статті 9 КУпАП) утворюють онтологічний компонент адміністративного делікту; їх встановлення і відповідна фіксація формують базові і відправні підстави для дослідницьких (гносеологічних) висновків і прийняття рішення про визнання діяння адміністративним проступком; г) дослідження суміжних понять кримінального i адміністративно-деліктного законодавства щодо змісту відповідальності за вчинення протиправних діянь доводять доречність визнання караності однією 3 необхідних ознак адміністративного проступку. 


\section{Література:}

1. Стовба А. В. Неклассическая правовая мысль на постсоветском пространстве. Антиномии. 2021. Т. 21, вып. 2. C. 73-89. DOI 10.17506/26867206_2021_21_2_73.

2. Стовба А. В. Классическая и неклассическая теория права. Вестник Томского государственного университета. 2021. № 463. C. 251-256. DOI: 10.17223/15617793/463/31

3. Колпаков В. К. Адміністративно-деліктний правовий феномен монографія. К.: Юрінком Інтер, 2004. 528 с.

4. Учение о феноменах позволяет найти взаимосвязи между теорией, методом и познающейся реальностью, позволяют вовлечь в теоретическую систему исследуемую действительность. См.: Леусенко Д. А. Николай Гартман и развитие исследовательских предпосылок анализа интегративности права. [Электронный ресурс]. Режим доступа: URL: https://events.spbu.ru/ eventsContent/events/2017/gartman/leusenko.pdf (дата обращения 23.04.2021).

5. Гартман Н. К основоположению онтологии. Перевод на русский язык: Ю. В. Медведев. СПб., 2003. [Электронный ресурс]. Режим доступа: URL: https://gtmarket.ru/library/basis/5683/5685 (дата обращения 23.04.2021).

6. Кодекс України про адміністративні правопорушення: Закон України від 07.12.1984 р. № 8073-Х. Відомості Верховної Ради Української РСР. 1984. № 51. Ст. 1122.

7. Постклассическая онтология права: монография С. И. Максимов, А. В. Поляков, А. В. Стовба, И. Л. Честнов и др.; общ. ред. И. Л. Честнов. Санкт-Петербург: Алетейя, 2016. 970с.

8. Колпаков В. К. Парадигма «поняття адміністративного права»: зміст і новели в системі універсалій. Питання адміністративного права. Харків Право, 2019. С. 48-75.

9. Колпаков В. К. Феноменология административного проступка. Moderní aspekty vědy: Svazek X mezinárodní kolektivní monografie. Oddíl 7 Mezinárodní Ekonomický Institut. Česká republika, Lázních-Praha: Mezinárodní Ekonomický Institut, 2021. Str. 230-240.

10.Велика українська юридична енциклопедія: у 20 т. Т. 5. Адміністративне право редкол. Ю. П. Битяк (голова) та інші. Х.: Право, 2020.960с.

11.Колпаков В. К. Адміністративне правопорушення i проступок: ґенеза нормативних ознак. Міжнародні і національні 
механізми прямої демократії: теорія і практика. Збірка наукових праць. Івано-Франківськ: НАIP, 2021. С. 168-174.

12. Кельман М. С., Мурашин О. Г. Загальна теорія права: підручник. К.: Кондор, 2002. 353 с.

13. Лазарев Б. М. Административные правонарушения и ответственность за их совершение. Советское государство и право. 1985. № 8. С. 28-41.

14. Колпаков В. К., Гордєєв В. В. Теорія адміністративного проступку: монографія. Х.: Харків юридичний, 2016. 344 с.

15. Колпаков В. К. Феномен «громадський порядок» в системі суміжних понять. Правові засади діяльності правоохоронних органів. Харків: Точка, 2020. С. 52-59.

16. Колпаков В. К. Зміст поняття «публічний порядок». Сучасне право в епоху соціальних змін. Матеріали XI Міжнародної науковопрактичної конференції. 26.02.2021. Т. 1. Київ: НАУ, 2021. C. 176-178.

17. Митний кодекс України: Закон України від 13.03.2012 р. № 4495-VI. Відомості Верховної Ради. 2012. № 44-48. Ст. 552.

18.Колпаков В. К. Протокол про адміністративне правопорушення. Велика українська юридична енциклопедія: у 20 т. Т. 5. Адміністративне право редкол. Ю. П. Битяк (голова) та інші. Х.: Право, 2021. С. 759. 